\title{
Proračunska transparentnost županija, gradova i općina: studeni 2020. - travanj 2021.
}

Bronić, Mihaela; Opačak, Marija; Ott, Katarina; Petrušić, Miroslav; Stanić, Branko

Source / Izvornik: Osvrti Instituta za javne financije, 2021, 14, 1 - 11

Journal article, Published version

Rad u časopisu, Objavljena verzija rada (izdavačev PDF)

https://doi.org/10.3326/ao.2021.119

Permanent link / Trajna poveznica: https://urn.nsk.hr/urn:nbn:hr:242:133341

Rights / Prava: Attribution-NonCommercial-NoDerivatives 4.0 International/ImenovanjeNekomercijalno-Bez prerada 4.0 međunarodna

Download date / Datum preuzimanja: 2023-04-26

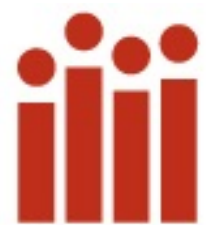

Repository / Repozitorij:

Institute of Public Finance Repository

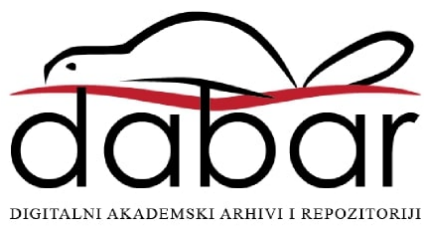



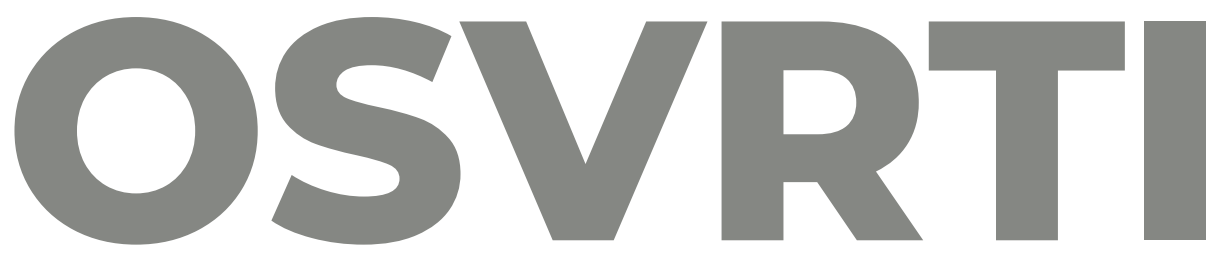

Instituta za javne financije

\title{
Proračunska transparentnost županija, gradova i općina: studeni 2020. - travanj 2021.
}

\author{
Mihaela Bronić, Marija Opačak, Katarina Ott, \\ Miroslav Petrušić, Branko Stanić \\ Institut za javne financije, Zagreb
}

Prosječna proračunska transparentnost svih hrvatskih lokalnih jedinica - izražena brojem ključnih proračunskih dokumenata objavljenih na njihovim mrežnim stranicama - iznosi 4,5 od mogućih 5. Sve županije objavile su svih 5 traženih dokumenata, gradovi prosječno 4,7 dokumenata, a općine prosječno 4,4 dokumenta. No, usprkos odličnim prosjecima, još uvijek 8\%, tj. 10 gradova i 16\%, tj. 68 općina ne objavljuje sva tri dokumenta za koje postoji zakonska obveza objave, a čak 20\% gradova i 37\% općina ne objavljuje dva dokumenta koje im je Ministarstvo financija preporučilo objavljivati. Naravno, sama objava ključnih proračunskih dokumenata ne znači apsolutnu transparentnost, no smatra se prvim korakom k višim razinama transparentnosti neophodnim za konstruktivno sudjelovanje građana u proračunskom procesu i kontroli prikupljanja i trošenja javnih 
sredstava. Sažetak rezultata za sve županije, gradove i općine slijedi u tekstu, a detalji su dostupni na interaktivnoj karti i u Excel tablici.

Institut za javne financije već duži niz godina analizira proračunsku transparentnost svih hrvatskih županija, gradova i općina, a u ovom se radu prikazuje sažetak rezultata najnovijeg istraživanja provedenog u razdobljima studeni-prosinac 2020. i veljača-travanj $2021 .^{2}$

Proračunska transparentnost podrazumijeva uvid u potpune, točne, pravovremene i razumljive proračunske informacije. Na temelju njih građani se mogu angažirati i pokušati utjecati na efikasnost prikupljanja i trošenja proračunskih sredstava, odgovornost Vlade i vlasti lokalnih jedinica ${ }^{3}$, kao i na smanjenje mogućih koruptivnih radnji.

\footnotetext{
1 Ovaj osvrt proizlazi iz projekta „Isplati li se transparentnost? Politički i socioekonomski učinci transparentnosti proračuna lokalnih jedinca u Hrvatskoj" (IP-2019-04-8360) koji financira Hrvatska zaklada za znanost (HRZZ). Rad poslijedoktorandice Marije Opačak također financira HRZZ. Mišljenja, nalazi, zaključci i preporuke su autorski i ne odražavaju nužno stajališta HRZZ-a. Autori zahvaljuju Filipu Badovincu na pomoći u prikupljanju podataka.

2 Rezultati prethodnih istraživanja objavljeni su u Ott, Bronić i Petrušić (2013, 2014, 2015), Ott, Bronić, Petrušić i Stanić (2016, 2017, 2018) te Ott, Bronić, Petrušić, Stanić i Prijaković (2019, 2020).

${ }^{3}$ Bez obzira na službeno razlikovanje jedinica lokalne i područne (regionalne) samouprave, pojam „lokalne jedinice" u ovom tekstu podrazumijeva svih 20 županija, 128 gradova i 428 općina.
} 
U ovom se istraživanju proračunska transparentnost mjeri brojem ključnih proračunskih dokumenata objavljenih na mrežnim stranicama lokalnih jedinica. ${ }^{4}$

To su:

- izvještaj o godišnjem izvršenju proračuna za 2019.;

- izvještaj o polugodišnjem izvršenju proračuna za 2020.;

- prijedlog proračuna za 2021.;

- izglasani proračun za 2021.;

- proračunski vodič za građane za $2021 .{ }^{5}$

Cilj je istraživanja utvrditi količinu ključnih proračunskih dokumenata objavljenih na mrežnim stranicama lokalnih jedinica, bez detaljnije analize njihova sadržaja. Naravno, uvijek postoji mogućnost da naši istraživači nisu pronašli neki od traženih dokumenata iako je objavljen na mrežnim stranicama, ali to vjerojatno znači da bi ih i građani teško našli jer nisu bili dovoljno dobro istaknuti. Nadalje, puka objava ovih pet ključnih proračunskih dokumenata ne znači da su te jedinice apsolutno proračunski transparentne niti da im je vodstvo apsolutno proračunski odgovorno, nego je samo potvrda da su se pridržavale Zakona o proračunu, Zakona o pravu na pristup informacijama i preporuka

\footnotetext{
${ }^{4}$ Pravila ovog istraživanja podrobno su opisana u Ott, Bronić, Petrušić, Stanić i Prijaković (2020).

${ }^{5}$ Od 2. studenoga do 31. prosinca 2020. analizirano je jesu li objavljeni izvještaji o godišnjem izvršenju proračuna za 2019. i o polugodišnjem izvršenju proračuna za 2020., a od 15. veljače do 14. travnja 2021. prijedlozi proračuna, izglasani proračuni i proračunski vodiči za građane za 2021. U obzir su uzeti samo dokumenti koji su se na mrežnim stranicama lokalnih jedinica nalazili u navedenim razdobljima istraživanja i to na dan pretraživanja njihove stranice. Naknadno objavljeni dokumenti se ne uvažavaju. Sve smo lokalne jedinice 14. listopada 2020. e-mailom obavijestili kada ćemo i na koji način pregledavati njihove mrežne stranice.
} 
Ministarstva financija. ${ }^{6}$ Ta razina proračunske transparentnosti može se smatrati tek prvim korakom prema potpunijoj transparentnosti, odnosno temeljnim preduvjetom za edukaciju građana o lokalnim proračunima. Samo se proračunski obrazovani i informirani građani mogu konstruktivno uključiti u lokalne proračunske procese, odnosno u odlučivanje o prikupljanju i potrošnji lokalnih sredstava i kontrolu odgovornosti lokalnih vlasti.

\section{Grafikon 1. Objavljeni proračunski dokumenti, 2015.-2021. (u \%)}

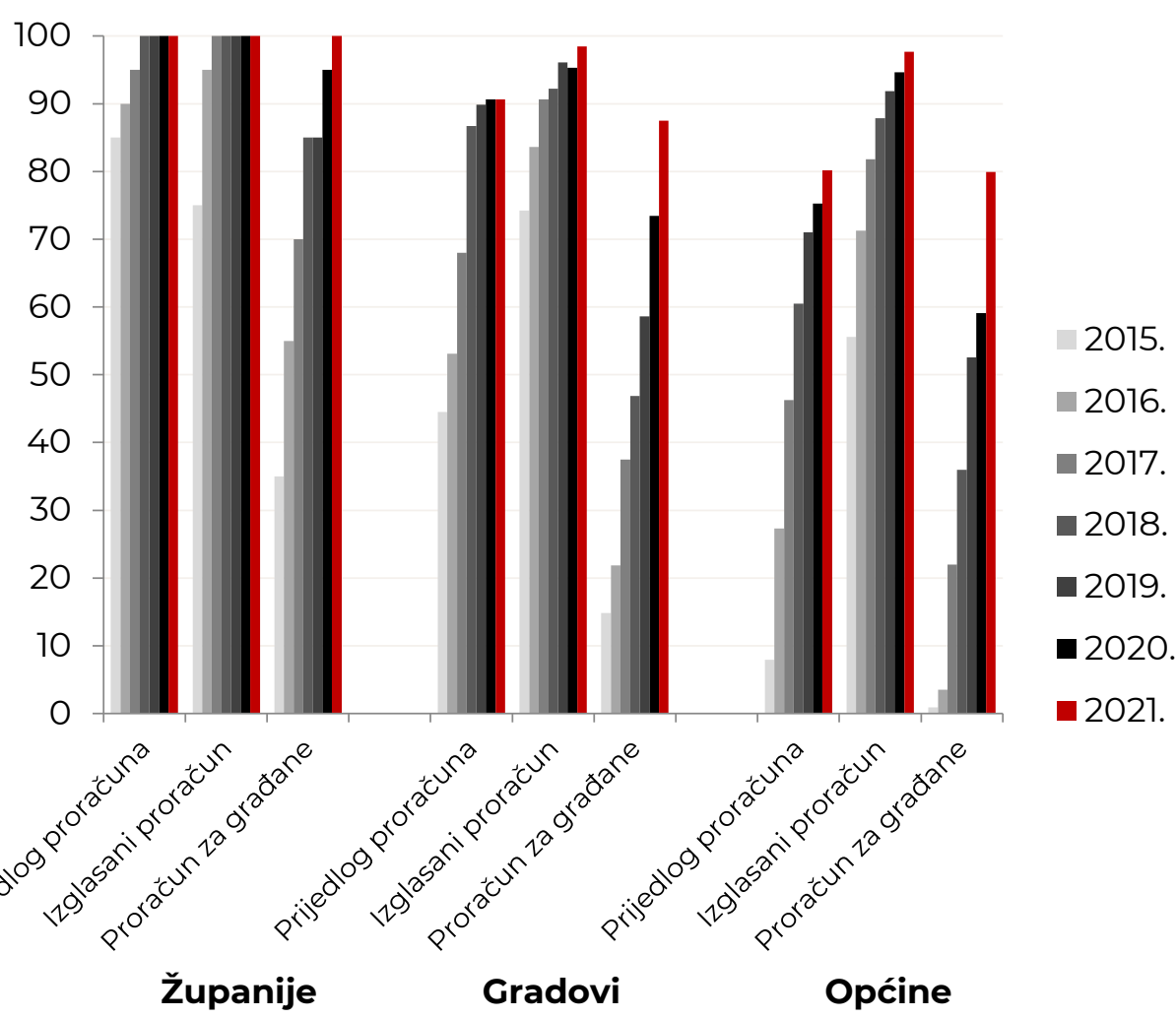

${ }^{6}$ Više o zakonodavnom okviru proračunske transparentnosti vidi u Ott, Bronić, Petrušić, Stanić i Prijaković (2020). 
U sedam ciklusa istraživanja, prosječna proračunska

transparentnost svih lokalnih jedinica porasla je s 1,8 u prvom na 4,5 u ovom, posljednjem ciklusu. Pomaci su primjetni kod svih vrsta lokalnih jedinica za sve proračunske dokumente, a to najbolje prikazuje objava proračuna za građane - 2015. ga je objavilo samo 1\% općina, a 2021. čak 80\% (Grafikon 1).

U ovom su ciklusu sve županije objavile svih pet proračunskih dokumenata, prosjek gradova je 4,7, a općina 4,4 (Grafikoni 2 i 3).

\section{Grafikon 2. Razina proračunske transparentnosti lokalnih jedinica, studeni 2020. - travanj 2021. (u \%)}

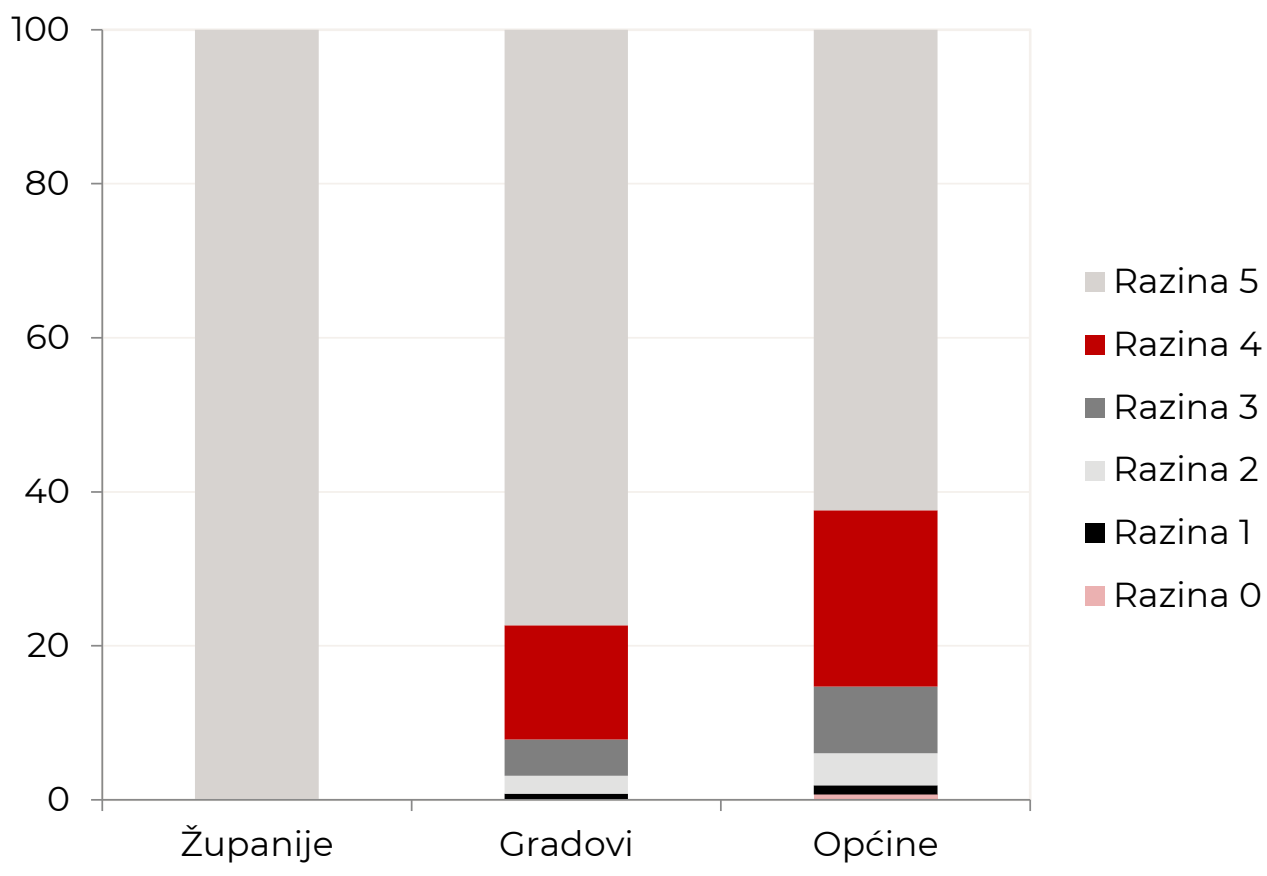


Grafikon 3. Objavljeni proračunski dokumenti, studeni 2020. - travanj 2021. (u \%)

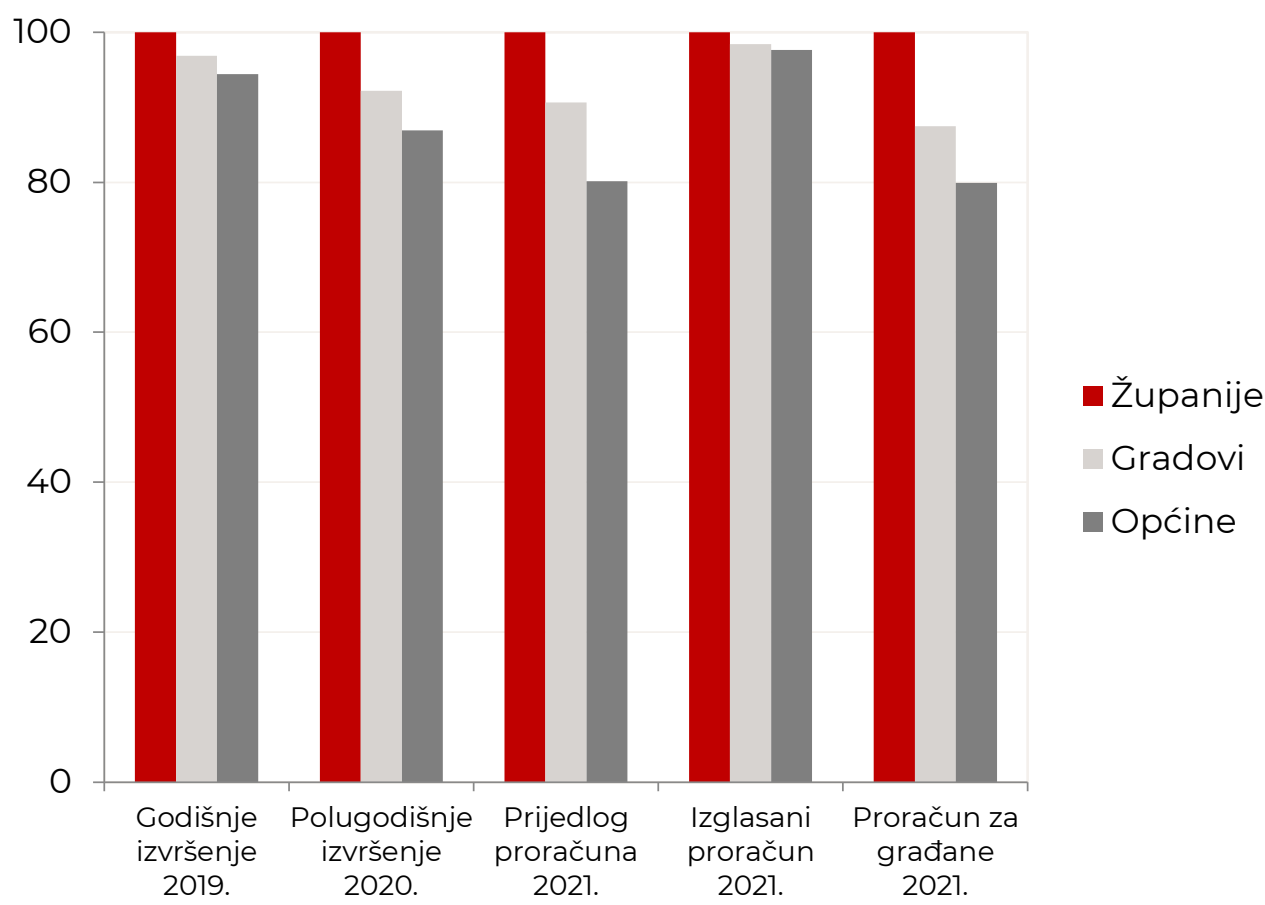

No, unatoč kontinuiranim poboljšanjima, u ovom posljednjem ciklusu tri općine nisu objavile niti jedan, a pet općina i jedan grad objavilo je samo po jedan proračunski dokument (Tablica 1 ). Još uvijek $8 \%$ gradova i 16\% općina ne objavljuje tri dokumenta koja su po zakonu obvezni objavljivati (izglasani proračun, polugodišnje i godišnje izvješće o izvršenju proračuna). Osim toga, 20\% gradova i 31\% općina ne pridržava se uputa Ministarstva financija i ne objavljuje dva dodatna dokumenta (prijedlog proračuna i proračunski vodič za građane). 


\section{Grafikon 4. Prosječna transparentnost općina}

i gradova (po županijama)

\section{Općine}

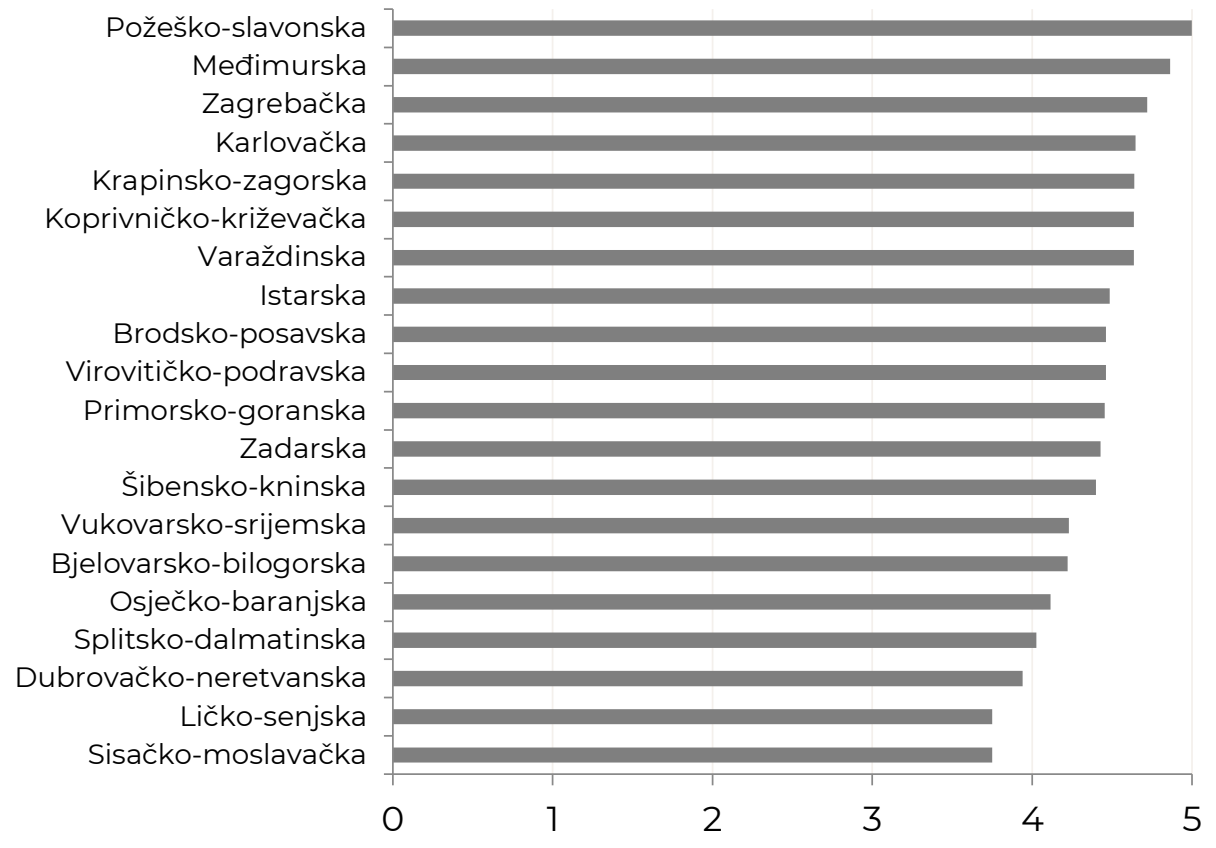

\section{Gradovi}
Bjelovarsko-bilogorska
Brodsko-posavska Karlovačka
Krapinsko-zagorska Međimurska
Primorsko-goranska Zagrebačka Dubrovačko-neretvanska Istarska
Osječko-baranjska Koprivničko-križevačka Varaždinska Zadarska
Splitsko-dalmatinska
Šibensko-kninska
Sisačko-moslavačka Ličko-senjska
Vukovarsko-srijemska Virovitičko-podravska Požeško-slavonska

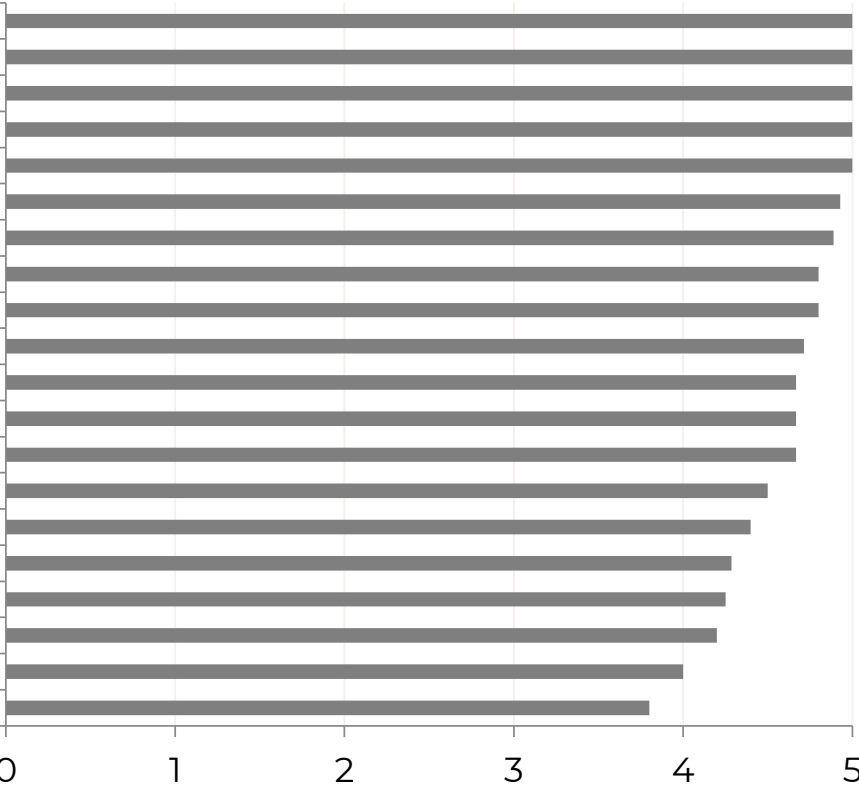


Prosječno su najmanje proračunskih dokumenata objavile općine u Sisačko-moslavačkoj i Ličko-senjskoj županiji (3,8 od 5). Sve općine Požeško-slavonske županije objavile su svih pet ključnih proračunskih dokumenata. Kad je riječ o gradovima, najmanje dokumenata objavili su gradovi upravo u Požeško-slavonskoj (3,8), a svi gradovi u čak pet županija objavili su sve ključne dokumente (Bjelovarsko-bilogorska, Brodsko-posavska, Karlovačka, Krapinskozagorska i Međimurska) (Grafikon 4).

Prema prosječnoj transparentnosti svih lokalnih jedinica na svome području, vodeće su Međimurska, Zagrebačka, Karlovačka i Krapinsko-zagorska, a na začelju se nalaze Sisačko-moslavačka, Ličko-senjska, Dubrovačko-neretvanska i Splitsko-dalmatinska (Grafikon 5).

\section{Grafikon 5. Ukupna prosječna transparentnost županija*}

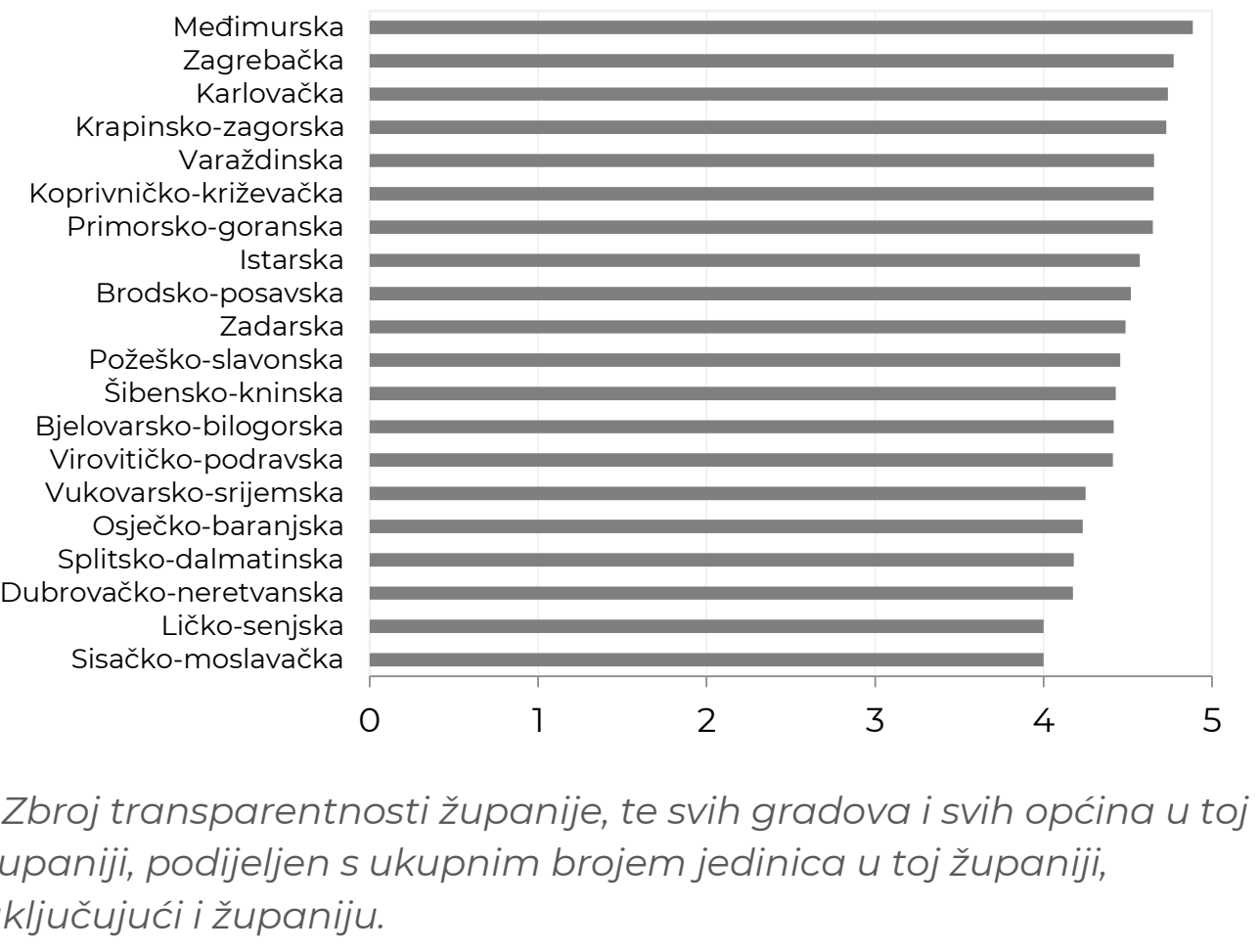


U usporedbi s prethodnim ciklusom, 11\% jedinica objavilo je manji broj dokumenata (uglavnom jedan ili dva dokumenta manje, dok su grad Pakrac i općina Višnjan objavili po tri dokumenta manje). Ohrabruje što je 30\% svih jedinica objavilo više dokumenata nego u prethodnom ciklusu (općina Galovac skočila je s nula na pet, a još osam općina objavilo je četiri dokumenta više - Bogdanovci, Donja Voća, Gorjani, Kolan, Lanišće, Lovreć, Sveti Filip i Jakov, te Vrbje). Pojedinosti o proračunskoj transparentnosti županija, gradova i općina dostupne su na interaktivnoj karti i u Excel tablici. Također, u našim prethodnim analizama proračunske transparentnosti ${ }^{7}$ nalaze se zaključci i preporuke koji mogu poslužiti kako za poboljšanje proračunske transparentnosti, tako i kao podloga za eventualnu reformu i fiskalnog i teritorijalnog ustroja države.

Tablica 1. Razina transparentnosti proračuna županija, gradova i općina (po broju objavljenih dokumenata, abecedno)

\begin{tabular}{|c|c|c|}
\hline \multicolumn{2}{|c|}{$\begin{array}{l}\text { RAZINA } \\
\text { OTVORENOSTI }\end{array}$} & LOKALNE JEDINICE \\
\hline & ŽUPANIJE & $\begin{array}{c}\text { Bjelovarsko-bilogorska, Brodsko-posavska, Dubrovačko- } \\
\text { neretvanska, Istarska, Karlovačka, Koprivničko-križevačka, } \\
\text { Krapinsko-zagorska, Ličko-senjska, Međimurska, Osječko- } \\
\text { baranjska, Požeško-slavonska, Primorsko-goranska, Sisačko- } \\
\text { moslavačka, Splitsko-dalmatinska, Šibensko-kninska, } \\
\text { Varaždinska, Virovitičko-podravska, Vukovarsko-srijemska, } \\
\text { Zadarska, Zagrebačka }\end{array}$ \\
\hline 5 & GRADOVI & $\begin{array}{l}\text { Bakar, Beli Manastir, Belišće, Benkovac, Bjelovar, Buzet, Cres, } \\
\text { Crikvenica, Čabar, Čakovec, Čazma, Daruvar, Delnice, Donja } \\
\text { Stubica, Drniš, Dubrovnik, Duga Resa, Dugo Selo, Đakovo, } \\
\text { Đurđevac, Garešnica, Glina, Gospić, Grubišno Polje, Hvar, } \\
\text { Imotski, Ivanec, Ivanić-Grad, Jastrebarsko, Karlovac, Kastav, } \\
\text { Kaštela, Klanjec, Komiža, Koprivnica, Korčula, Kraljevica, } \\
\text { Krapina, Krk, Kutina, Labin, Lepoglava, Lipik, Ludbreg, } \\
\text { Makarska, Mali Lošinj, Metković, Mursko Središće, Našice, Nin, } \\
\text { Nova Gradiška, Novalja, Novigrad, Novska, Ogulin, Opatija, } \\
\text { Oroslavje, Osijek, Otok, Ozalj, Pag, Pazin, Pleternica, Ploče, } \\
\text { Popovača, Poreč, Požega, Pregrada, Prelog, Pula, Rab, Rijeka, }\end{array}$ \\
\hline
\end{tabular}

${ }^{7}$ Vidi primjerice: Ott at al (2019). 


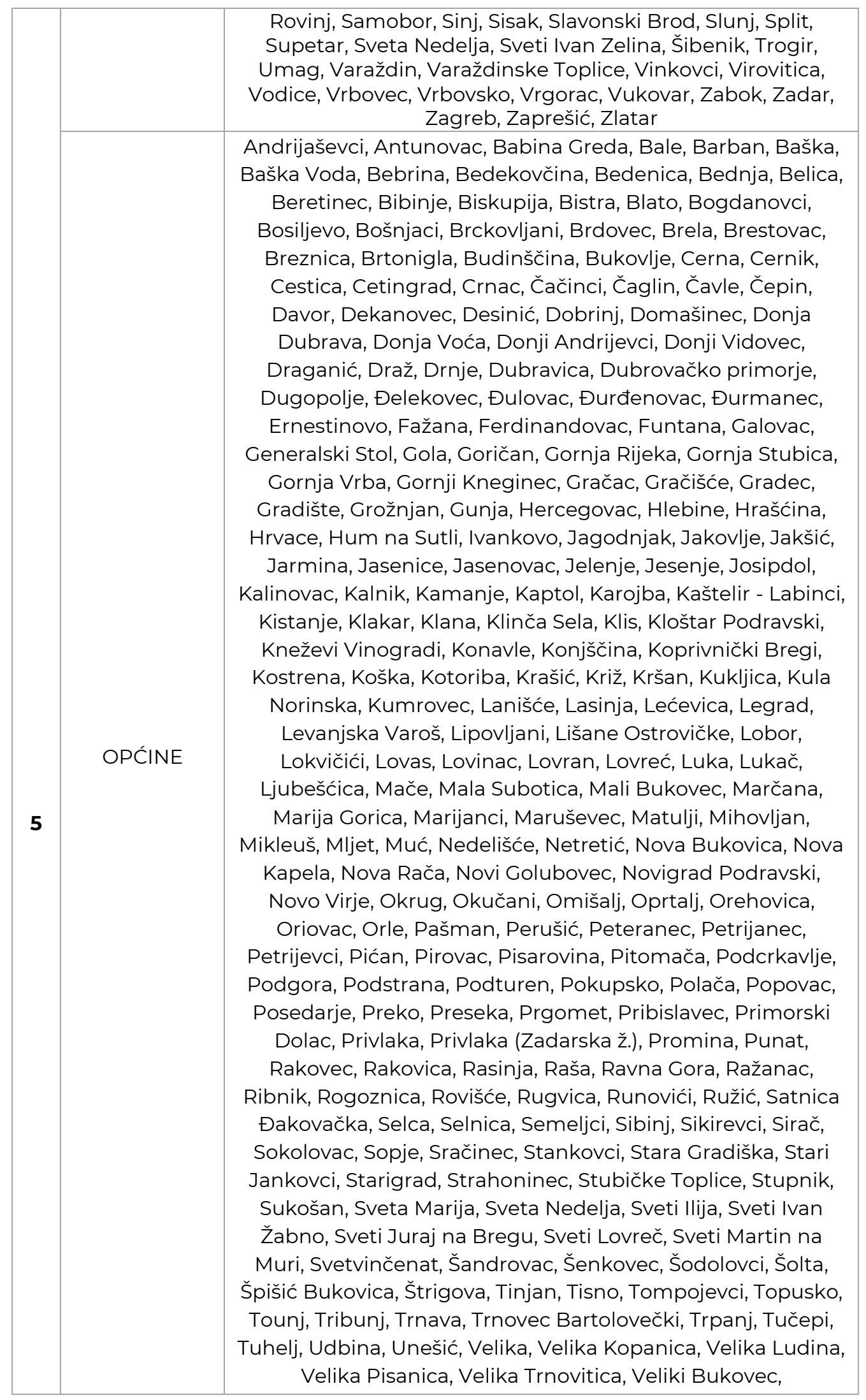




\begin{tabular}{|c|c|c|}
\hline 5 & & $\begin{array}{c}\text { Veliki Grđevac, Veliko Trojstvo, Vidovec, Vir, Virje, Visoko, } \\
\text { Viškovo, Vižinada, Vladislavci, Vojnić, Vratišinec, Vrpolje, Vrsi, } \\
\text { Zagorska Sela, Zemunik Donji, Zlatar Bistrica, Zmijavci, } \\
\text { Žakanje, Žminj, Žumberak, Župa dubrovačka }\end{array}$ \\
\hline \multirow[b]{2}{*}{4} & GRADOVI & $\begin{array}{c}\text { Biograd na Moru, Buje, Donji Miholjac, Ilok, Križevci, Novi } \\
\text { Vinodolski, Obrovac, Opuzen, Orahovica, Petrinja, Senj, } \\
\text { Skradin, Solin, Stari Grad, Valpovo, Velika Gorica, Vis, Vodnjan, } \\
\text { Vrlika }\end{array}$ \\
\hline & OPĆINE & $\begin{array}{c}\text { Barilović, Berek, Bilice, Bilje, Bizovac, Bol, Brinje, Brodski } \\
\text { Stupnik, Cerovlje, Cista Provo, Civljane, Čađavica, Darda, } \\
\text { Dežanovac, Dicmo, Donja Motičina, Dragalić, Drenovci, } \\
\text { Dubrava, Dugi Rat, Farkaševac, Fužine, Gorjani, Gornji } \\
\text { Mihaljevec, Hrvatska Dubica, Jalžabet, Kali, Kanfanar, Kloštar } \\
\text { Ivanić, Kolan, Končanica, Koprivnički Ivanec, Krapinske } \\
\text { Toplice, Krnjak, Ližnjan, Lokve, Lopar, Lumbarda, Lupoglav, } \\
\text { Magadenovac, Malinska-Dubašnica, Marija Bistrica, } \\
\text { Markušica, Martijanec, Martinska Ves, Medulin, Milna, Molve, } \\
\text { Mošćenička Draga, Motovun, Murter, Novigrad, Nuštar, } \\
\text { Oprisavci, Orebić, Petlovac, Plitvička Jezera, Podgorač, } \\
\text { Podravske Sesvete, Poličnik, Postira, Primošten, Pučišća, } \\
\text { Radoboj, Rešetari, Sali, Seget, Skrad, Slavonski Šamac, } \\
\text { Smokvica, Ston, Strizivojna, Suhopolje, Sunja, Sutivan, Sveti } \\
\text { Đurđ, Sveti Filip i Jakov, Sveti Križ Začretje, Škabrnja, } \\
\text { Štefanje, Tar-Vabriga, Tkon, Tovarnik, Trpinja, Vela Luka, } \\
\text { Veliko Trgovišće, Vinica, Vinodolska općina, Viškovci, Voćin, } \\
\text { Vrbanja, Vrbje, Vrbnik, Vrhovine, Vuka, Zadvarje, Zagvozd, } \\
\text { Zažablje }\end{array}$ \\
\hline \multirow[b]{2}{*}{3} & GRADOVI & Knin, Novi Marof, Omiš, Otočac, Slatina, Trilj \\
\hline & OPĆINE & $\begin{array}{c}\text { Borovo, Breznički Hum, Brod Moravice, Donji Kraljevec, Donji } \\
\text { Kukuruzari, Ervenik, Feričanci, Garčin, Gornji Bogićevci, } \\
\text { Gradac, Gradina, Gundinci, Gvozd, Ivanska, Jelsa, Kapela, } \\
\text { Klenovnik, Kraljevec na Sutli, Kravarsko, Lastovo, Majur, } \\
\text { Marina, Mrkopalj, Negoslavci, Nijemci, Petrovsko, Plaški, } \\
\text { Podravska Moslavina, Pušća, Saborsko, Stari Mikanovci, Staro } \\
\text { Petrovo Selo, Sveti Petar u Šumi, Štitar, Tordinci, Vođinci, } \\
\text { Zdenci }\end{array}$ \\
\hline \multirow[b]{2}{*}{2} & GRADOVI & Kutjevo, Pakrac, Županja \\
\hline & OPĆINE & $\begin{array}{l}\text { Čeminac, Drenje, Dvor, Erdut, Janjina, Karlobag, Kijevo, } \\
\text { Lekenik, Otok, Pakoštane, Podbablje, Proložac, Severin, } \\
\text { Slivno, Sućuraj, Viljevo, Vrsar, Zrinski Topolovac }\end{array}$ \\
\hline \multirow{2}{*}{1} & GRADOVI & Hrvatska Kostajnica \\
\hline & OPĆINE & Donji Lapac, Pojezerje, Punitovci, Šestanovac, Višnjan \\
\hline 0 & OPĆINE & Nerežišća, Povljana, Sveti Petar Orehovec \\
\hline
\end{tabular}

